\title{
Hoe divers, invloedrijk en deliberatief is een G1000?
}

\author{
Het ontwerp van een burgertop en de verwezenlijking van \\ democratische waarden*
}

\author{
Ank Michels \& Harmen Binnema
}

\begin{abstract}
In navolging van de G1000 in België waren er G1000's in Amersfoort, Kruiskamp, Uden en Groningen en een burgertop in Amsterdam met een vergelijkbare opzet. In deze bijdrage is gekeken naar het ontwerp van deze burgertoppen en de bijdrage die ze leveren aan een aantal belangrijke democratische waarden. Wat is de diversiteit van de deelnemers, de invloed op het beleid en de kwaliteit van de gesprekken tijdens de burgertop? Het onderzoek laat zien dat de diversiteit van de groep deelnemers beperkt is. De gekozen selectiemethode, of nu gekozen wordt voor loting of voor een open uitnodiging, maakt weinig uit voor de diversiteit van de groep deelnemers. Verder blijkt dat de invloed van de burgertoppen op het beleid en de politiek nagenoeg ontbreekt. De onderwerpen die uit de burgertoppen naar voren komen, komen niet terug in het lokale beleid, ook niet bij de burgertop in Uden, waar de gemeenteraad het initiatief tot een G1000 heeft genomen. Tot slot kwalificeren deelnemers over het algemeen het gesprek aan tafel als constructief en inspirerend. De vorm van de dialoog heeft in beperkte mate invloed op de mate waarin deelnemers zich gehoord voelen en zich vrij voelen om te zeggen wat ze willen.
\end{abstract}

\section{Inleiding}

De afgelopen anderhalf jaar zijn er in Nederland tal van G1000's en andere burgertoppen georganiseerd. In navolging van de G1000 in België, waarvan de Belgische schrijver David Van Reybrouck een van de organisatoren was, waren er G1000's in Amersfoort, Kruiskamp (een wijk in Amersfoort), Uden en Groningen. Vergelijkbare burgertoppen waren er ook in onder meer Amsterdam (over 250 vraagstukken in de stad), Maastricht (over gezondheidszorg) en Utrecht (over duurzaamheid). Ondertussen dienen zich alweer nieuwe voorbeelden aan, waaronder een initiatief tot een burgerraad in de gemeente Peel en Maas, een G1000 in Nijmegen en de Haagse Krach 1000. Alle initiatieven pogen burgers een belangrijkere stem te geven en de democratie te vernieuwen of te 'verfrissen' (G1000.nu; burgertop-amsterdam.nl). De burgertoppen beogen zowel het creëren van een eigen agenda en zeggenschap als het uitoefenen van invloed op het lokale beleid.

* De auteurs doen, in samenwerking met onderzoekers van de Universiteit Leiden en de Vrije Universiteit Amsterdam en met steun van het Ministerie van Binnenlandse Zaken en Koninkrijksrelaties, onderzoek naar de G1000 en andere burgertoppen. De auteurs danken Lars Brummel voor zijn bijdrage aan de analyse van de kwantitatieve data. 
Hoog tijd om deze nieuwe democratische vormen nader te beschouwen en te onderzoeken in hoeverre ze bijdragen aan de verwezenlijking van een aantal democratische waarden.

In deze bijdrage bespreken we de designs van de burgertoppen in Amersfoort (inclusief die in de wijk Kruiskamp), Uden, Amsterdam en Groningen. We onderzoeken wat hun bijdrage is aan een aantal centrale democratische waarden: insluiting, invloed en deliberatie. De centrale vraag van dit artikel is: wat is de bijdrage van de onderzochte burgertoppen aan de verwezenlijking van de democratische waarden insluiting, invloed en deliberatie? We zijn daarbij geïnteresseerd in de vraag of het ontwerp van de burgertop hierbij een verschil maakt: wat is bevorderlijk of bezwaarlijk voor het realiseren van deze democratische waarden?

De onderzochte vijf burgertoppen zijn in een aantal opzichten vergelijkbaar. Overal zijn burgers uitgenodigd om ideeën uit te werken over de toekomst van hun stad of wijk. Er is een specifieke dag uitgekozen om de burgertop te houden, op een fysieke locatie, en de bijeenkomst verloopt volgens een vooraf vastgesteld programma. Maar daarnaast zijn er belangrijke verschillen in het ontwerp van het forum. Die verschillen hebben met name betrekking op: de selectie van de deelnemers, de betrokkenheid van het college van burgemeester en wethouders en de gemeenteraad en de wijze van communicatie tijdens de bijeenkomst.

Dit artikel is als volgt opgebouwd. Na een introductie van de belangrijkste kenmerken van een burgertop als voorbeeld van een deliberatief forum, introduceren we een analysekader om de verwezenlijking van democratische waarden te evalueren. Vervolgens bespreken we het ontwerp van de vijf burgertoppen. Daarna onderzoeken we de bijdrage van elke burgertop aan de realisatie van een aantal democratische waarden. We sluiten af met een aantal conclusies over de relatie tussen het gekozen ontwerp en de realisatie van de democratische waarden.

\section{De burgertop als voorbeeld van een deliberatief forum}

De Engelse politicoloog Graham Smith onderscheidt in zijn boek Democratic innovations (2009) drie vormen van democratische innovatie. Als eerste noemt hij de volksvergaderingen ('popular assemblies'). Kenmerkend voor volksvergaderingen is dat grote groepen mensen in een vergadering bijeenkomen en beslissen over lokale onderwerpen of de begroting. Als voorbeelden noemt hij de 'New England town meetings' en vormen van participatiebudgetten waarbij burgers zelf beslissen over de besteding van het budget in hun wijk of stad. De meest institutionele vorm hiervan is te vinden in Porto Alegre in Brazilië. Een tweede vorm die Smith onderscheidt, is de directe democratie via de stembus, ofwel het referendum. Referenda geven individuele burgers direct een stem in de politieke besluitvorming. Smith benadrukt dat het hier gaat om die vormen van een referendum die bindend zijn en dus niet alleen maar adviserend. 
In dit artikel staat een derde vorm van democratische vernieuwing centraal die Smith onderscheidt: de 'mini-publics'. Mini-publics worden ook wel deliberatieve fora genoemd en zijn een overkoepelend begrip voor verschillende typen fora, waaronder burgerfora, burgerjury's en consensusconferenties (Smith, 2009: 72-79; Michels, 2011b, 2012). De selectie van de deelnemers is erop gericht om de diversiteit van de groep te waarborgen. Een gemeenschappelijk kenmerk van al deze fora is verder dat de nadruk sterk wordt gelegd op het proces en het volgen van procedures die van belang zijn voor het creëren van een ideale omgeving voor deliberatie. Meningsvorming en uitwisseling van argumenten zijn belangrijker dan besluitvorming en de nadruk ligt meestal op het zoeken naar consensus.

Voorbeelden van deliberatieve fora zijn vooral te vinden in het buitenland. Zo was er in Canada in 2004 de British Columbia Citizens' Assembly (BCCA), ingesteld door de regering van British Columbia, die bestond uit 160 willekeurig gekozen burgers die gedurende elf maanden leerden en delibereerden over een verandering van het kiesstelsel en uiteindelijk met een advies aan de regering kwamen. Andere bekende voorbeelden zijn het 'Australian Citizens' Parliament' van 150 burgers in Australië, dat een uitspraak deed over de toekomst van het politieke systeem in Australië (Dryzek, 2009), de 'Icelandic Constitutional Council' (Landemore, 2015) en natuurlijk de G1000 in België over de toekomst van België (Van Reybrouck, 2013; Caluwaerts \& Reuchamps, 2014b). De al eerder genoemde consensusconferenties zijn weer een ander voorbeeld. Deze worden sinds de jaren tachtig in Denemarken geregeld gehouden over wetenschappelijke en technologische ontwikkelingen. De visie van gewone burgers wordt belangrijk gevonden als het gaat om technologische ontwikkelingen met belangrijke sociale en ethische consequenties.

Tot slot kunnen we hier de 'deliberative poll' niet onvermeld laten, een creatie van de Amerikaanse democratietheoreticus James Fishkin (http://cdd.stanford.edu/). Het grote verschil met de andere vormen van deliberatieve fora is dat hier burgers niet wordt gevraagd om een gemeenschappelijk advies of idee, maar in plaats daarvan vullen individuele burgers vóór en na de deliberatieve bijeenkomst van het forum vragenlijsten in waarin naar hun kennis en mening over het onderwerp wordt gevraagd. De gedachte is dat burgers door deliberatie beter tot weloverwogen standpunten kunnen komen.

Hoewel deliberatieve fora in Nederland veel minder vaak voorkomen dan in landen als Australië, Duitsland en Denemarken, hebben sommige Nederlandse gemeenten in de afgelopen tien jaar burgerfora en burgerjury's als vorm ingezet om burgers te betrekken bij het beleid en de politiek. Het bekendste deliberatief forum is het Burgerforum Kiesstelsel geweest, dat in 2006 advies uitbracht aan het kabinet. Op lokaal niveau zijn er qua opzet vergelijkbare deliberatieve fora geweest: onder meer in 2006 in Amsterdam over de luchtkwaliteit, in 2010 in Oude IJsselstreek over de verdeling van voorzieningen over de kernen van de gemeente en in Rotterdam, waar sinds begin 2015 een burgerjury van 150 Rotterdammers tweemaal per jaar het beleid van de gemeente beoordeelt en advies geeft. Hoewel de details van de opzet van de fora verschillen, is er in al deze geval- 
len sprake van een deliberatief proces en van een aselect gekozen groep burgers, waarbij rekening is gehouden met een aantal achtergrondkenmerken, zoals geslacht, leeftijd en opleiding (Leyenaar, 2009; website gemeente Oude IJsselstreek; website gemeente Rotterdam).

Deze voorbeelden laten zien dat er een grote verscheidenheid aan vormen van burgerparticipatie is. Dit is ook een van de conclusies die Fung (2015) trekt in een terugblik op de ontwikkeling van participatief bestuur in de afgelopen twintig jaar: er heeft veel innovatie plaatsgevonden in de manier waarop burgers kunnen meepraten en invloed uitoefenen. Burgerparticipatie is flink in omvang gegroeid en kan op steeds meer beleidsonderwerpen betrekking hebben. Een andere trend is dat het initiatief voor participatie van verschillende actoren kan komen: van binnen en buiten de overheid, van maatschappelijke organisaties, van ambtenaren of van politici. Dit is ook bij de burgertoppen terug te zien.

\section{Een analysekader om de verwezenlijking van democratische waarden te evalueren}

Hoewel sommige theoretici de negatieve kanten van participatie benadrukken, zoals dat massale participatie zou leiden tot een dalende consensus over basisnormen van onze democratie (Dahl, 1956; Sartori, 1987), hebben zich in de afgelopen decennia verschillende benaderingen ontwikkeld die het belang van burgerparticipatie voor de kwaliteit van de democratie onderstrepen. In deze normatieve participatieve-democratietheorieën wordt gesteld dat het afstaan van besluitvormingsmacht aan volksvertegenwoordigers ertoe heeft geleid dat burgers zich vervreemd voelen van de politiek. Deze theorieën beschouwen burgerparticipatie als de kern van democratie. Deze gedachte is ontleend aan Rousseau: zijn visie dat participatie van iedere individuele burger in de politieke besluitvorming van belang is voor het functioneren van de staat, vormt de grondslag voor veel theorieën over participatieve democratie. De basis voor het politieke systeem is volgens Rousseau het sociale contract, dat inhoudt dat burgers vrijwillig afzien van hun eigen wensen en beslissen om vrij te zijn door te beslissen over de wetten die hen regeren. In de latere theorieën over participatieve democratie wordt benadrukt dat participatie zich niet zou moeten beperken tot de politieke besluitvorming, maar ook een plaats zou moeten krijgen op het werk en in de lokale gemeenschap (Pateman, 1970; Barber, 1984).

Participatie geeft, volgens deze theoretische stroming, burgers zeggenschap in de besluitvorming en daarmee invloed op het besluitvormingsproces. Daarnaast heeft participatie verschillende andere functies in een democratie. Zo heeft participatie een educatieve functie: burgers vergroten hun burgerschapsvaardigheden en dat maakt hen vaardiger als ze deelnemen aan besluitvormingsprocessen. Ook heeft participatie een integratiefunctie, waarmee wordt bedoeld dat burgers zich door te participeren meer publieke burgers gaan voelen en zich meer betrokken voelen bij de gemeenschap en de publieke zaak. Dat kan ertoe bijdragen dat ze zich meer verantwoordelijk voelen voor politieke besluiten. Tot slot draagt parti- 
cipatie bij aan een grotere legitimiteit van beslissingen. In navolging van Rousseau stellen de participatieve-democratietheorieën dat participatie een belangrijke functie vervult in het maken van regels die voor iedereen acceptabel zijn.

In aanvulling hierop wordt door theoretici van de deliberatieve democratie gesteld dat de essentie van democratische legitimiteit is gelegen in het feit dat mensen die worden geraakt door een besluit ook betrokken worden in het overleg over dat besluit (Dryzek \& List, 2003; Gastil \& Levine, 2005). Volgens de deliberatieve-democratietheorieën zijn overleg en uitwisseling van argumenten (deliberatie), en dus niet het tellen van stemmen, de essentiële mechanismen voor politieke besluitvorming (Gutmann \& Thompson, 2004; Fishkin \& Laslett, 2002; Elster, 1998). Onder theoretici bestaat verschil van mening over de plek waar deliberatie plaats zou moeten vinden. Verschillende fora worden genoemd, variërend van deskundigenforums tot burgerpanels (Fishkin \& Laslett, 2002). Maar alle theoretici zijn het erover eens dat deliberatie betekent dat discussie en uitwisseling van argumenten, waarbij individuen hun opvattingen uiteenzetten en rechtvaardigen, gepaard gaan met de bereidheid om ook van opvatting te veranderen. Een deliberatief proces houdt per definitie in dat bovendien sprake is van gelijkheid, deelname van verschillende belangen en achtergronden van mensen en wederzijds respect.

Hoewel critici van mening zijn dat deliberatie hoge en onrealistische eisen stelt aan burgers (Mutz, 2006), stellen deliberatieve-democratietheorieën dat deliberatie leidt tot rationele collectieve uitkomsten en, omdat ieder individu een gelijke stem heeft en de mogelijkheid om de anderen te overtuigen, de kans geeft aan minderheden en individuen om zich te laten horen. Daar komt bij dat theoretici van de deliberatieve school ervan overtuigd zijn dat deliberatie bijdraagt aan de legitimiteit van beslissingen (Hendriks e.a., 2007).

Samenvattend: burgerparticipatie draagt in de visie van deze theoretici bij aan het bereiken van bepaalde democratische waarden. Hoewel elke benadering weer andere accenten legt, kunnen we een aantal democratische waarden onderscheiden (voor een nadere uitwerking hiervan, zie Smith, 2009; Michels, 2011a, 2011b; Michels \& De Graaf, 2010). Burgerparticipatie:

- geeft individuele burgers een stem in het beleidsproces. Insluiting heeft betrekking op de mate waarin burgers uit diverse sociale groepen participeren en er geen sprake is van de uitsluiting van bepaalde groepen;

- geeft burgers zeggenschap in besluitvorming (invloed). Dit betreft de invloed die deelnemers hebben op de verschillende fasen van het besluitvormingsproces;

- leidt tot rationele beslissingen op basis van uitwisseling van argumenten (deliberatie); Deliberatie heeft betrekking op dialoog tussen deelnemers en de uitwisseling van argumenten op basis van gelijkheid en wederzijds respect;

- leidt tot meer democratische vaardigheden en meer betrokkenheid bij en verantwoordelijkheid voor de gemeenschap, en stimuleert zo democratisch burgerschap; en 
- vergroot de legitimiteit van beslissingen. Legitimiteit heeft betrekking op de steun van de deelnemers voor het proces en de uitkomsten van het proces.

In deze bijdrage beperken we ons tot de eerste drie waarden: insluiting, invloed en deliberatie. ${ }^{1}$ We sluiten hiermee aan bij Fung (2006), die in zijn werk veronderstelt dat een aantal kenmerken van het ontwerp van burgerparticipatie (de wijze van selectie, de relatie met het beleid en de communicatie van de deelnemers) van invloed is op de feitelijke werking van participatie. De democratische waarden insluiting, invloed en deliberatie sluiten nauw aan bij deze aspecten van het ontwerp (zie ook Ercan \& Hendriks, 2013). Daarnaast zijn dit ook de waarden die centraal staan in de ambities van de onderzochte burgertoppen. Zo stelt het Platform G1000 dat de G1000 een ontmoeting is tussen burgers van verschillende groepen, jong of oud, rijk of arm, autochtoon of allochtoon, die via dialogen en open gesprekken op zoek gaan naar onderwerpen die zij gezamenlijk belangrijk vinden voor hun stad, dorp of wijk (www.g1000.nu). De G1000 wordt gepresenteerd als een aanvulling op het huidige democratische bestel.

\section{Methoden}

De vijf burgertoppen die in een vergelijkende casestudy worden onderzocht, zijn gehouden tussen maart 2014 en juni 2015. Het gaat in chronologische volgorde om de gemeenten Amersfoort (gehele stad en de wijk Kruiskamp), Uden, Amsterdam en Groningen. Alle bijeenkomsten, met uitzondering van Amsterdam, droegen de naam G1000. Deze cases zijn in belangrijke mate vergelijkbaar, omdat zij alle beoogden om een grote en divers samengestelde groep burgers op een fysieke locatie met elkaar te laten denken en spreken over wat voor hun gemeente belangrijk was. In een aantal opzichten - wel of geen loting, wel of geen relatie met de politiek vooraf, inrichting van de dialoog - verschillen zij van elkaar (zoals hierna wordt uitgewerkt).

Om te kunnen vaststellen in hoeverre deze burgertoppen insluiting, invloed en deliberatie verwezenlijken, hebben we deze drie democratische waarden geoperationaliseerd in evaluatievragen en thema's. Deze zijn in tabel 1 weergegeven.

Voor onze bevindingen hebben we gebruik gemaakt van verschillende bronnen. Ten eerste digitale surveys ${ }^{2}$ die voorafgaand aan en na afloop van de bijeenkomst onder de deelnemers zijn gehouden. In deze surveys wordt gevraagd naar de achtergronden van de deelnemers, de mate waarin zij maatschappelijk actief zijn, contacten met hun buurtgenoten, verantwoordelijkheidsgevoel voor de buurt en

1 Andere waarden, zoals burgerschap, transparantie en legitimiteit, laten we buiten beschouwing (Michels \& Binnema, 2015).

2 De surveys zijn afgenomen en technisch ondersteund door bureau MarketResponse (market response.nl). Het aantal deelnemers dat de surveys heeft ingevuld, varieert: 124 in Amersfoort, 112 in Groningen, 59 in Amsterdam, 40 in Uden en 33 in Kruiskamp. De respons ligt gemiddeld op iets meer dan $25 \%$. 


\section{Tabel 1 Democratische waarden en thema's}

\begin{tabular}{llll}
\hline $\begin{array}{l}\text { Democratische } \\
\text { waarden }\end{array}$ & Evaluatievragen & Thema's & Bronnen \\
\hline Insluiting & $\begin{array}{l}\text { Hoe divers is de deel- } \\
\text { nemersgroep? }\end{array}$ & Selectie en diversiteit & Surveys, observaties \\
Invloed & $\begin{array}{l}\text { Wat gebeurt er met } \\
\text { de input en ideeën van } \\
\text { deelnemers? }\end{array}$ & $\begin{array}{l}\text { Doorwerking in agen- } \\
\text { davorming en beleid }\end{array}$ & $\begin{array}{l}\text { Interviews, websites, } \\
\text { krantenartikelen, } \\
\text { documenten }\end{array}$ \\
In hoeverre is er & $\begin{array}{l}\text { Kwaliteit gesprekken, } \\
\text { sprake van dialoog tus- } \\
\text { sen dialoog en uitwisseling } \\
\text { senemers? }\end{array}$ & $\begin{array}{l}\text { Surveys, observaties, } \\
\text { interviews }\end{array}$ \\
& & & \\
\hline
\end{tabular}

hun houding ten aanzien van de (lokale) politiek. De meting na afloop vraagt specifiek naar hoe zij het deelnemen aan de G1000 hebben ervaren, hoe de gesprekken zijn verlopen, welke nieuwe inzichten zij hebben opgedaan en of zij aan de voorstellen die zijn gedaan zelf actief vervolg willen geven. De resultaten van de surveys zijn terug te vinden in onze bevindingen over insluiting en deliberatie.

Ten tweede hebben we nieuwsbrieven, websites, hand-outs en documenten geanalyseerd die zijn gepubliceerd door de organisaties van de burgertoppen. Dit is aangevuld met relevante krantenartikelen uit de lokale media. Deze informatie is met name gebruikt voor het aspect 'invloed' en bovendien om preciezer het design van de verschillende burgertoppen te kunnen weergeven.

Ten derde hebben we interviews afgenomen met raadsleden, wethouders, ambtenaren en organisatoren. Bij de selectie van raadsleden hebben we gelet op spreiding naar grote en kleine partijen respectievelijk coalitie en oppositie. In totaal zijn er 23 interviews gehouden. Het betrof semigestructureerde interviews die zijn gehouden op de werkplek van de respondenten. In deze interviews zijn de volgende thema's aan de orde gesteld: de mate van bekendheid en betrokkenheid bij de G1000; de rol van de overheid in de relatie tot burgers; de uitkomsten van de G1000 en de invloed op politiek en bestuur; de toekomst van de G1000. De bevindingen uit deze interviews komen met name terug in het deel over invloed. In de interviews is ook gevraagd naar de ervaringen van politici en ambtenaren met de gesprekken aan de tafels; dit komt terug in de bevindingen over deliberatie.

Tot slot hebben we als onderzoekers geobserveerd tijdens de G1000's in Kruiskamp, Uden en Groningen en de burgertop in Amsterdam. Gedurende de dag hebben we gesprekken aan tafels meegemaakt en daarnaast in de pauzes korte gesprekken gehad met deelnemers en organisatoren. Deze observaties geven een aanvullend beeld van insluiting en deliberatie. 


\section{Het ontwerp van de burgertop}

Als het gaat om het ontwerpen van een burgerparticipatie is, in navolging van de Amerikaanse politicoloog Fung (2006), een aantal vragen van belang, namelijk: (1) wie nemen er deel aan de bijeenkomst, (2) wat is de relatie met het beleid, en (3) hoe communiceren de deelnemers met elkaar? Het antwoord op de eerste vraag kan variëren van deelname door iedereen die dat wil (open zelfselectie) tot specifieke werving onder bepaalde groepen of willekeurige selectie van deelnemers uit de gehele populatie. Het antwoord op de tweede vraag over de relatie met het beleid varieert van geen invloed van de deelnemers op het beleid tot directe zeggenschap. En het antwoord op de derde vraag varieert van luisteren en ideeën naar voren brengen tot deliberatie en onderhandeling (Fung, 2006).

Hieronder gaan we in op de wijze van selectie, de relatie met de politiek en het beleid, en de organisatie van de communicatie tijdens de bijeenkomst.

\subsection{Selectie}

In Amersfoort is een combinatie van loting en gerichte werving toegepast. Onder alle inwoners van Amersfoort is geloot uit de Basisregistratie personen. Er zijn 6000 mensen geloot en uitgenodigd via een brief van de burgemeester. De andere groepen, namelijk werkgevers, politici, ambtenaren en kunstenaars, zijn gericht geworven; degenen die wilden deelnemen, konden zichzelf aanmelden. Bij meer dan 600 aanmeldingen van burgers zou er een tweede loting volgen (www. g1000amersfoort.nl), maar deze heeft niet plaatsgevonden. Uiteindelijk zijn er 530 mensen geweest, onder wie 354 burgers, 40 politici, 40 ambtenaren, 44 werkgevers en 52 kunstenaars.

In Uden is gewerkt met een open uitnodiging. Alle inwoners kregen een brief die was gericht 'aan de bewoners'. Iedereen kon zich vrij aanmelden. Het regieteam besloot hiertoe over te gaan nadat was gebleken dat de plaatselijke verordening en het 'Privacyreglement Basisregistratie Personen van de gemeente Uden' een trekking uit het GBA-bestand niet toelieten. Daarnaast is geworven via de lokale media, posters en een website en zijn verenigingen en maatschappelijke instellingen bezocht. Bij 1000 aanmeldingen zou worden geloot. Uiteindelijk waren er ongeveer 250 gewone burgers aanwezig en daarnaast zo'n 20 raadsleden.

In de wijk Kruiskamp in de gemeente Amersfoort zijn 2000 mensen geselecteerd op basis van loting. Toen de loting niet meer dan 20 tot 30 aanmeldingen opleverde, is overgegaan tot flyeren, nogmaals brieven sturen, contacten via sleutelfiguren en op straat mensen aanspreken. De WijkG1000 Kruiskamp was verspreid over vijf bijeenkomsten. Bij de eerste bijeenkomst waren er ongeveer 110 deelnemers, bij de laatste 14.

Voor de selectie van de deelnemers aan de burgertop in Amsterdam is geen gebruik gemaakt van loting. Iedereen van 16 jaar en ouder die woonachtig is in Amsterdam mocht meedoen aan de Burgertop. Wel zijn er zogeheten ambassadeurs ingezet. Deze ambassadeurs, die een groot aantal organisaties vertegen- 
woordigden, hebben gericht via hun netwerk mensen benaderd. Daarnaast is er geworven via de lokale media en is de organisatie de straat op gegaan om mensen rechtstreeks te benaderen. Uiteindelijk waren er 250 mensen op de dag zelf, onder wie ongeveer 15 (voormalige) gemeenteraadsleden en leden van bestuurscommissies.

In Groningen is net als in Amersfoort geloot onder alle inwoners van de stad, de 'Stadjers'. Onder inwoners van boven de 18 jaar zijn 10.000 mensen geloot. Dat leverde in eerste instantie een aanmelding op van ongeveer 400 burgers. Eén maand voor de G1000 is er nog een herinneringsbrief gestuurd naar de gelote inwoners van de stad, waarna het aantal aanmeldingen boven de 600 uitkwam. Daarnaast is gericht geworven onder 'frisdenkers', mensen van wie wordt verwacht dat ze buiten de vastomlijnde kaders kunnen denken. Uiteindelijk zijn er in totaal zo'n 450 mensen geweest (de tafelhosts niet meegerekend), onder wie een aantal raadsleden.

\subsection{De relatie met de politiek en het beleid}

In Amersfoort kwam het initiatief voor de G1000 van een groep enthousiaste burgers, die zich door Van Reybrouck hadden laten inspireren. Hoewel er de nodige contacten waren met zowel politieke als ambtelijke spelers in Amersfoort en de gemeente faciliteerde met geld en het loten en uitnodigen van deelnemers, kunnen we zeggen dat de G1000 bottom-up door burgers is georganiseerd. De agenda voor de bijeenkomst was vrij en er hoefde geen relatie te worden gelegd met gemeentelijk beleid. Wel werd de Agenda voor Amersfoort aan de burgemeester aangeboden.

In Uden kwam het idee om een G1000 te organiseren op tijdens een conferentie van de net gekozen gemeenteraad. Diverse raadsleden bleven ook betrokken bij de organisatie, die overigens wel voor het grootste deel uit burgers bestond en aansluiting vond bij een eerder gehouden participatietraject, 'Udenaar de toekomst'. Omdat het initiatief vanuit de gemeenteraad kwam, lag er een directere verbinding met politiek en beleid en was de verwachting dat de raad iets met de uitkomsten zou gaan doen.

De G1000 in Kruiskamp was een uitvloeisel van de G1000 Amersfoort, waar als een van de tien thema's de WijkG1000 werd vastgesteld. Deze G1000 was nadrukkelijk op de eigen wijk gericht en niet op de gemeenteraad. Wel zijn er raadsleden aanwezig geweest bij één of meer bijeenkomsten tussen oktober 2014 en januari 2015.

Het initiatief voor de burgertop in Amsterdam kwam van een groep burgers, die zich onder meer zorgen makten over de lage opkomst bij de gemeenteraadsverkiezingen. De burgemeester en de raadsleden werden geïnformeerd over de burgertop en spraken hun waardering uit, maar er was geen ondersteuning vanuit de gemeente. De agenda van de bijeenkomst was vooraf gestructureerd, doordat er online 35 thema's waren gekozen om het de rest van de dag over te hebben. 
Inhoudelijk hadden deze thema's verbinding met politiek en beleid, maar hier was niet op gestuurd.

Ook in Groningen kwam het initiatief van een groep enthousiaste burgers. Onder hen bevond zich één D66-raadslid, maar zij deed dit in de rol van burger en niet van raadslid. Twee wethouders ondersteunden het initiatief door als ambassadeur van de G1000 Groningen op te treden en tijdens de G1000 waren de burgemeester en een aantal raadsleden van de coalitiepartijen aanwezig. De agenda voor de G1000 was volledig open; een relatie met het gemeentelijk beleid hoefde niet te worden gelegd.

\subsection{De communicatie tijdens de bijeenkomst}

Op het eerste gezicht is de setting bij alle onderzochte G1000's dezelfde: mensen zitten aan tafels en praten met elkaar over ideeën voor de toekomst van hun wijk of gemeente. In de wijze waarop het proces van de G1000's vorm heeft gekregen, zien we echter grote verschillen.

De G1000 in Amersfoort vond plaats op 22 maart 2014 en duurde één dag. De bijeenkomst startte met drie vragen aan de deelnemers, namelijk: (1) wat vind jij belangrijk in Amersfoort voor de komende vier jaar, (2) wat moet daarvoor gebeuren, en (3) wat kun/wil jij daaraan bijdragen? Deze vragen werden besproken in wisselende combinaties van deelnemers. De antwoorden, steeds via één steekwoord, van alle deelnemers op de drie vragen werden verzameld. $\mathrm{Na} 75$ minuten werd duidelijk welke onderwerpen het meest genoemd waren en daarmee ook wat de onderwerpen voor de rest van de dag zouden worden (G1000 Amersfoort 2014). Daarna gingen de deelnemers uiteen in kleine groepen; elke groep ging in gesprek met elkaar over een van de onderwerpen. De deelnemers zelf bepaalden dus de agenda van de dag.

De G1000 in Uden vond plaats op 4 oktober 2014 en duurde een dag. De bijeenkomst startte met de vraag: welke tien ideeën wilt u inbrengen voor de toekomst van Uden? Daarna werd de lange lijst van ideeën ingekort door middel van handopsteken per tafel. In de volgende ronde werden de ideeën van verschillende tafels bijeengebracht en moest er opnieuw gestemd worden, deze keer door middel van het plakken van stickers. Uiteindelijk leidde het hele proces van brainstormen over ideeën en vervolgens samenvoegen van ideeën en daarover stemmen tot tien initiatieven voor Uden (hand-out dagprogramma G1000 Uden; G1000 Uden 2014). Aan het einde van de dag konden deelnemers zich opgeven om één of meer initiatieven verder uit te werken.

In Kruiskamp is de G1000 verspreid over vijf bijeenkomsten. De eerste vond plaats op 15 oktober 2014. Tijdens deze bijeenkomst kozen de deelnemers de thema's waarmee ze verder wilden. De methodiek is dezelfde als die in Amersfoort gebruikt is, dat wil zeggen dat de drie vragen - (1) wat vind jij belangrijk in Kruiskamp, (2) wat moet daarvoor gebeuren, en (3) wat kun/wil jij daaraan bijdragen? - de agenda voor de overige bijeenkomsten opleverden. In drie werkgroepavonden zijn de thema's verder uitgewerkt, waarbij in de eerste bijeenkomst 'dro- 
men' centraal stond, in de tweede 'denken', en in de derde 'doen'. Op de slotbijeenkomst, de eindconferentie op 16 en 17 januari 2015, werd de uitwerking van de voorstellen gepresenteerd, werden keuzes gemaakt, en werd een begin gemaakt met een plan van aanpak voor de uitwerking.

De Burgertop in Amsterdam was op 6 juni 2015 en duurde één dag. Op de Burgertop werd gesproken over onderwerpen die door de deelnemers zelf waren aangedragen toen zij zich via de website aanmeldden. Dit leidde tot 35 thema's met bijbehorende tafels. De deelnemers vonden bij binnenkomst een overzicht van de thema's en kozen het definitieve onderwerp waarover ze die dag wilden praten pas op de Burgertop zelf. Ze gingen aan die tafel zitten en bleven in veel gevallen de rest van de dag aan dezelfde tafel. De opdracht voor de ochtend was om een 'uitdagende vraag' te formuleren bij het thema (Burgertop Amsterdam 2015). In de middag werden in twee rondes eerst oplossingen bij deze vraag bedacht en vervolgens werden ze in concrete ideeën uitgewerkt: dit waren er in totaal 57.

De G1000 in Groningen was eveneens op 6 juni en duurde één dag. De bijeenkomst startte met de volgende vraag aan de deelnemers: wat vind jij belangrijk voor Groningen en wat is daarvoor nodig? Deze vragen werden aan alle tafels besproken in wisselende combinaties van deelnemers. De antwoorden van alle deelnemers werden verzameld en de onderwerpen die het meest genoemd waren, bepaalden de agenda van de middag (G1000 Groningen 2015). In de middag gingen de deelnemers uiteen in kleine groepen; elke groep ging aan de slag om het door hen gekozen thema verder uit te werken. Uiteindelijk stemden alle aanwezigen over de uitgewerkte projecten en kwam een top 10 tot stand.

In tabel 2 staan de belangrijkste kenmerken van het ontwerp van de onderzochte burgertoppen nog eens samengevat. Het gaat hier om de kenmerken van het ontwerp en niet om de resultaten. Deze komen in paragraaf 8 aan de orde.

\section{Insluiting, invloed en deliberatie}

\subsection{Insluiting en diversiteit}

De typische deelnemer aan alle onderzochte burgertoppen is geboren en getogen in Nederland, ouder dan 50 jaar, en heeft een hbo- of academische opleiding. Dat wil niet zeggen dat mensen met andere achtergrondkenmerken niet aanwezig zijn, maar ze zijn sterk ondervertegenwoordigd (zie tabel 3). De typische deelnemer is verder iemand die stemt, maar opvallend genoeg niet noodzakelijkerwijs ook iemand die al actief is bij wijkavonden, burgerpanels of bewonerscommissies. Wel zijn het vaak mensen die al betrokken zijn bij buurtactiviteiten. De typische deelnemer is, tot slot, niet cynisch als het gaat om het functioneren van de gemeenteraad en het gemeentebestuur. ${ }^{3}$

3 De gemiddelde score op een vijfpuntsschaal voor politiek cynisme, waarbij 1 staat voor politiek cynisch, is steeds boven de 3.0 (met als hoogste 3.30 in Amersfoort). Amsterdam vormt hierop een uitzondering met een score van 2.90 . 
Tabel 2 Kenmerken van het ontwerp van de burgertoppen

\begin{tabular}{|c|c|c|c|}
\hline & Selectie & $\begin{array}{l}\text { Relatie met politiek } \\
\text { en beleid }\end{array}$ & Communicatie \\
\hline Amersfoort & $\begin{array}{l}\text { Loting en gerichte } \\
\text { werving onder speci- } \\
\text { fieke groepen }\end{array}$ & $\begin{array}{l}\text { Initiatief van burgers; } \\
\text { weinig sturing op rela- } \\
\text { tie met beleid }\end{array}$ & $\begin{array}{l}\text { Vorm: gesprek tussen } \\
\text { deelnemers, 'word } \\
\text { cloud'; één dag; } \\
\text { thema's ter plekke } \\
\text { bepaald }\end{array}$ \\
\hline Uden & Open uitnodiging & $\begin{array}{l}\text { Initiatief van gemeen- } \\
\text { teraad, waardoor ver- } \\
\text { binding met de politiek }\end{array}$ & $\begin{array}{l}\text { Vorm: brainstorm en } \\
\text { stemmen; één dag; } \\
\text { thema's ter plekke } \\
\text { bepaald }\end{array}$ \\
\hline Kruiskamp & $\begin{array}{l}\text { Eerst loting, daarna } \\
\text { open uitnodiging }\end{array}$ & $\begin{array}{l}\text { Initiatief van burgers; } \\
\text { gericht op de eigen } \\
\text { wijk }\end{array}$ & $\begin{array}{l}\text { Vorm: gesprek tussen } \\
\text { deelnemers; verspreid } \\
\text { over vijf bijeenkom- } \\
\text { sten }\end{array}$ \\
\hline Amsterdam & $\begin{array}{l}\text { Open uitnodiging en } \\
\text { gerichte werving }\end{array}$ & $\begin{array}{l}\text { Initiatief van burgers; } \\
\text { weinig sturing op rela- } \\
\text { tie met beleid }\end{array}$ & $\begin{array}{l}\text { Vorm: gesprek tussen } \\
\text { deelnemers, vragen en } \\
\text { stellingen; één dag; } \\
\text { thema's vooraf bepaald }\end{array}$ \\
\hline Groningen & $\begin{array}{l}\text { Loting en beperkt } \\
\text { gerichte werving }\end{array}$ & $\begin{array}{l}\text { Initiatief van burgers; } \\
\text { weinig sturing op rela- } \\
\text { tie met beleid }\end{array}$ & $\begin{array}{l}\text { Vorm: gesprek tussen } \\
\text { deelnemers, 'word } \\
\text { cloud'; één dag; } \\
\text { thema's ter plekke } \\
\text { bepaald }\end{array}$ \\
\hline
\end{tabular}

In Amersfoort is er een zekere diversiteit doordat ook werkgevers en kunstenaars zijn uitgenodigd. Kijken we naar de achtergrondkenmerken van de deelnemers, dan valt vooral op dat de deelnemers van 50 jaar en ouder sterk vertegenwoordigd zijn, evenals de hogeropgeleiden. De deelname van mensen met een nietwesterse achtergrond is beperkt.

In Uden valt vooral op dat er veel ouderen zijn en weinig jongeren. Mensen met een niet-Europese achtergrond waren maar heel beperkt aanwezig. Volgens een van de initiatiefnemers van de G1000 Uden heeft de beperkte aanwezigheid van jongeren en mensen met een niet-westerse achtergrond voor een deel te maken met de keuze van de betreffende dag: het was zaterdag (veel andere activiteiten voor jongeren) en het was de dag van het Offerfeest. Bij de keuze van de datum was men zich van dit laatste niet bewust.

In Kruiskamp is de groep hogeropgeleiden sterk vertegenwoordigd. Wat betreft leeftijd is vooral de middengroep tussen 30 en 50 jaar aanwezig. Opnieuw zijn mensen met andere achtergronden dan de Nederlandse zwak vertegenwoordigd, terwijl Kruiskamp een wijk is met zeer veel verschillende nationaliteiten; meer dan $38 \%$ behoort tot de groep met een niet-westerse achtergrond (Amersfoort in cijfers 2015). Tijdens de laatste bijeenkomst van de G1000 Kruiskamp waren er nog veertien deelnemers, van wie niemand jonger dan 35 jaar en één met een niet-westerse achtergrond (observatie onderzoekers). 
In Amsterdam zijn opnieuw de hogeropgeleiden sterk vertegenwoordigd. De surveygegevens laten ook zien dat er veel ouderen aanwezig waren, hoewel observaties ter plekke dat beeld enigszins nuanceren. En opnieuw is de groep met een niet-westerse achtergrond beperkt; al is die groter dan bij de andere burgertoppen, vergeleken met de Amsterdamse bevolking gaat het om een duidelijke ondervertegenwoordiging.

Tabel 3 Achtergrondkenmerken deelnemers in percentages 4

\begin{tabular}{lrrrrrr}
\hline & & $\begin{array}{r}\text { Amers- } \\
\text { foort }\end{array}$ & Uden & Kruiskamp & $\begin{array}{r}\text { Amster- } \\
\text { dam }\end{array}$ & Groningen \\
\hline Opleiding & Laag & 8 & 15 & 6 & 11 & 9 \\
& Midden & 15 & 28 & 9 & 14 & 14 \\
& Hoog & 77 & 57 & 85 & 75 & 77 \\
Leeftijd & $16-29$ & 5 & 2 & 9 & 12 & 14 \\
& $30-49$ & 35 & 20 & 64 & 10 & 31 \\
& 50 en ouder & 60 & 78 & 27 & 78 & 55 \\
Etnische & Nederlands & n.b. & 90 & 97 & 79 & 84 \\
achtergrond & Westers & n.b. & 2 & 0 & 7 & 8 \\
& Niet-westers & n.b. & 8 & 3 & 14 & 8 \\
\hline
\end{tabular}

In Groningen valt vooral op dat alle leeftijdscategorieën goed vertegenwoordigd zijn. In vergelijking met de meeste burgertoppen zijn er ook wat meer jongeren. Verder is het patroon hetzelfde als bij de overige burgertoppen: het opleidingsniveau van de deelnemers is hoog en de achtergrond van de deelnemers is overwegend Nederlands.

\subsection{Invloed}

De burgertoppen kunnen op verschillende manieren invloed hebben op politiek en beleid. In de meest directe variant worden de voorstellen uit een burgertop door de gemeenteraad op de agenda gezet en onderdeel van politieke besluitvorming. We kijken echter ook naar invloed die minder direct is, zoals het opnieuw onder de aandacht brengen van thema's die minder prioriteit hadden in de

4 De tabel is samengesteld op basis van de surveys en de gevonden patronen zijn geverifieerd op basis van observaties ter plekke en interviews met de initiatiefnemers en organisatoren. Precieze cijfers zijn niet te geven omdat wij geen inzicht mogen hebben in de persoonsgegevens van deelnemers. Politici, ambtenaren en gespreksleiders zijn buiten de analyse gehouden. Opleidingsniveau, leeftijd en etnische achtergrond zijn vergeleken met de CBS-cijfers voor de betreffende gemeenten en getoetst met $\chi^{2}$ voor goodness of fit, $\mathrm{p}<, 01$. Wat betreft de verdeling naar opleiding en leeftijd wijkt de G1000 in alle gemeenten significant af, bij etniciteit geldt dit voor Amsterdam en Kruiskamp, in Amersfoort is dit niet in de survey opgenomen. Vergelijking tussen de gemeenten laat zien dat in Uden minder hoogopgeleiden hebben deelgenomen, in Kruiskamp juist meer. Kruiskamp, Uden en Amsterdam wijken af als het gaat om leeftijd: in het eerste geval waren er significant meer 30'ers en 40'ers, in de laatste twee juist meer in de groep van 50 jaar en ouder. 
gemeenteraad of meer openheid voor nieuwe vormen van burgerparticipatie: in hoeverre zit het betrekken van burgers meer tussen de oren van ambtenaren en politici?

De G1000 in Amersfoort leverde aan het eind van de dag een top 10 op van thema's voor de stad. Hoewel de burgemeester deze in ontvangst heeft genomen, is de top 10 niet gepresenteerd als een 'wensenlijstje' voor de gemeenteraad (of voor het college), maar als een agenda waarmee de Amersfoorters zelf iets moeten gaan doen. De raadsleden ervaren dit ook zo: ze kunnen zich de gekozen thema's nog herinneren en vinden ze belangrijk, maar de thema's zijn niet op de agenda van de raad gekomen. Omdat de top 10 tamelijk abstracte thema's bevat, is lastig vast te stellen of de G1000 invloed heeft gehad. Bij een aantal onderwerpen bleek dat die voor een belangrijk deel al onderdeel waren van het bestaande beleid van de gemeente. Sommige onderwerpen zijn meer gericht op sociale cohesie en actief worden in de eigen buurt en vragen geen rol van de gemeente. In Amersfoort zijn plannen voor een gelote burgerraad, die dichter op het werk van de gemeenteraad zal gaan opereren, en voor een tweede G1000 in 2016.

Wanneer we de top 10 in Uden bekijken, valt op dat die in een aantal opzichten concreter is geformuleerd dan in Amersfoort en dat een aantal thema's directe invloed op het beleid beoogt. Een paar thema's staan al op de agenda van de gemeente en zo kan er een mooie aansluiting met de G1000-deelnemers tot stand komen, die kunnen meepraten en meedenken. Ook in Uden zijn er thema's gekozen waarmee de inwoners prima zelf aan de slag kunnen en de gemeente(raad) niet per se nodig is. De raadsleden geven aan dat er geen onderwerp vanuit de G1000 op de raadsagenda is gekomen, maar zij zeggen wel rekening te houden met de uitkomsten en bij nieuw beleid vaker burgers te raadplegen en voor die input open te staan.

De ideeën die uit de G1000 in Kruiskamp naar voren zijn gekomen, zijn vooral bedoeld als een agenda waarmee de bewoners zelf aan de slag gaan. Het contact met de gemeente is beperkt en betreft vooral praktische kwesties, zoals het contact leggen met de wijkagent of het houden van een multiculturele maaltijd. Wel lijkt het idee van een G1000 op wijkniveau navolging te krijgen in andere wijken in Amersfoort, zoals Zielhorst en Kattenbroek.

In Amsterdam is zowel voorafgaand aan de burgertop als na afloop ervan door de organisatie ingesproken bij de raadscommissie en een van de wethouders heeft de ideeën van de burgertop in ontvangst genomen. In tegenstelling tot de G1000's is er geen top 10 uit gekomen, maar een verzameling van bijna zestig ideeën. In een aantal gevallen vragen die ideeën ondersteuning of beleid van de gemeente, maar het is onduidelijk hoe deze verbinding tot stand moet komen. De reactie van de raadsleden in de commissie was gematigd positief, maar er zijn geen afspraken gemaakt over een vervolg en er zijn nog geen onderwerpen uit de burgertop op de raadsagenda gekomen. Wel zijn er gesprekken geweest met bijna alle bestuurscommissies in de stadsdelen. 
In Groningen leverde de dag een top 10 van ideeën op die voor een deel een beroep doen op beleid van de gemeente. De top 10 is niet aangeboden aan de gemeente. Wel hebben twee wethouders het initiatief voor de G1000 ondersteund en waren de burgemeester, ambtenaren en enkele raadsleden bij de G1000 aanwezig. De organisatie van de G1000 zoekt naar manieren om een verbinding met de gemeente tot stand te brengen door ambtenaren te betrekken bij de ontwikkeling van initiatieven en in gesprek te gaan met de gemeenteraad over de ideeën van de G1000.

\subsection{Deliberatie}

Om te bepalen in hoeverre er sprake is van dialoog tussen de deelnemers rapporteren we hier over de ervaringen van de deelnemers zelf. In de surveys is hierover een aantal vragen gesteld. Tabel 4 laat zien hoe de respondenten verschillende aspecten van de gesprekken aan tafel waarderen. Het gaat hier over de volgende vragen:

- In hoeverre voelde u zich aan uw tafel vrij om te zeggen wat u wilde?

- In hoeverre voelde u zich aan uw tafel gehoord door uw gesprekspartners?

- Hadden uw gesprekspartners een constructieve bijdrage aan de dialoog?

Daarnaast werd in de survey gevraagd welke trefwoorden men bij het gesprek vond passen, met opties als inspirerend en ontspannen, maar ook moeizaam en ingewikkeld.

Tabel $4 \quad$ Waardering kwaliteit gesprekken (percentage dat een positief tot zeer positief antwoord geeft $)^{5}$

\begin{tabular}{lrrrrr}
\hline & $\begin{array}{r}\text { Amers- } \\
\text { foort }\end{array}$ & Uden & Kruiskamp & $\begin{array}{r}\text { Amster- } \\
\text { dam }\end{array}$ & Groningen \\
\hline Vrij om alles te zeggen & 81,5 & 82,5 & 71,4 & 88,9 & 83,9 \\
Voelt zich gehoord & 72,6 & 60 & 42,8 & 82,2 & 72,3 \\
$\begin{array}{l}\text { Constructieve bijdrage } \\
\text { anderen }\end{array}$ & n.b. & 57,5 & 42,8 & 82,2 & 59,8 \\
\hline
\end{tabular}

In Amersfoort kwalificeren de respondenten het groepsgesprek vooral als constructief, inspirerend en gelijkwaardig. De waardering van de kwaliteit van de dialoog is hoog. Deelnemers voelen zich vrij om te zeggen wat ze willen en voelen zich ook gehoord.

5 Respondenten kunnen via een schuif een antwoord geven, waarbij het beginpunt staat voor bijvoorbeeld 'voel mij helemaal niet gehoord' en het eindpunt voor 'heel erg gehoord'. In de tabel zijn de resultaten vertaald naar een 100-puntsschaal en is alleen het antwoord weergegeven van de respondenten die tussen de 70 en 100 hebben geantwoord. Het aantal respondenten dat deze vragen heeft beantwoord, is 124 voor Amersfoort, 40 voor Uden, 14 voor Kruiskamp, 112 voor Groningen en 18 voor Amsterdam. Kruiskamp en Amsterdam wijken significant af van de andere gemeenten op de onderwerpen 'gehoord voelen' en 'constructieve bijdrage anderen' $\left(\chi^{2}, \mathrm{p}<, 01\right)$. In Amsterdam ligt de waardering hoger dan het gemiddelde, in Kruiskamp lager. 
In Uden ervaart men het gesprek als constructief en ontspannen. Maar ongeveer een vierde kwalificeert het gesprek ook als moeizaam. Ook hier voelt een ruime meerderheid zich vrij om zich uit te spreken. De mate waarin men zich gehoord voelt, ligt lager dan in Amersfoort. En iets meer dan de meerderheid beoordeelt de bijdrage van anderen als constructief.

In Kruiskamp wordt het gesprek gekwalificeerd als ontspannen en gelijkwaardig. De waardering van de dialoog is duidelijk lager dan bij de andere burgertoppen. Slechts $42,8 \%$ voelt zich gehoord en beoordeelt de bijdrage van anderen als constructief.

In Amsterdam worden de gesprekken omschreven als ontspannen en inspirerend. De waardering van de kwaliteit van de dialoog is erg hoog. Opvallend is ook dat men in Amsterdam van alle G1000's het meest positief oordeelt over de bijdragen van anderen.

De gesprekken in Groningen worden door de deelnemers omschreven als constructief, ontspannen en inspirerend. De waardering van de kwaliteit van de dialoog is in Groningen hoog en vergelijkbaar met het oordeel hierover in Amersfoort.

In de interviews kwam naar voren dat ook politici en ambtenaren de gesprekken als erg positief hadden ervaren. Dit kwam met name omdat er in hun ogen open en kritisch, maar ook constructief werd gesproken. Bovendien vond men de ideeën en de voorstellen die werden gedaan realistisch, waarbij niet alleen naar de overheid werd gekeken, maar burgers er ook over nadachten wat zij zelf konden doen om plannen tot uitvoering te brengen.

\section{Ontwerp en verwezenlijking van democratische waarden}

$\mathrm{Nu}$ we de kenmerken van de designs en de realisatie van drie democratische waarden hebben besproken, is de vraag of er sprake is van een verband tussen een bepaald type design en een bepaalde uitkomst. Tabel 5 geeft een overzicht van de gevonden relaties tussen ontwerp en uitkomsten.

Het eerste wat opvalt, is dat de gekozen selectiemethode, of nu gekozen wordt voor loting of voor een open uitnodiging, weinig uitmaakt voor de diversiteit van de groep deelnemers. De diversiteit van de groep deelnemers (insluiting) is beperkt: weinig jongeren, weinig lageropgeleiden en weinig met een niet-westerse achtergrond. In de door ons onderzochte burgertoppen blijkt dat dit geldt voor zowel de groep die zich aanmeldt na ingeloot te zijn als de groep die deelneemt na een open uitnodiging, zoals in Uden en Amsterdam. Bovendien is het aantal aanmeldingen te klein voor een verdere selectie in vervolg op de loting.

Ten tweede valt op dat het voor de invloed op de politiek niet uitmaakt of het initiatief voor de burgertop is genomen door burgers of door de gemeenteraad. De invloed van de burgertoppen op het beleid en de politiek ontbreekt nagenoeg 
Tabel 5 Relaties tussen het ontwerp en de verwezenlijking van democratische waarden

\begin{tabular}{|c|c|c|}
\hline & Insluiting & \\
\hline Selectie & Diversiteit groot & Diversiteit beperkt \\
\hline $\begin{array}{l}\text { Loting als belangrijke compo- } \\
\text { nent van selectie }\end{array}$ & & $\begin{array}{l}\text { Amersfoort; Groningen } \\
\text { Kruiskamp }\end{array}$ \\
\hline \multirow[t]{2}{*}{ Geen loting } & & Uden; Amsterdam \\
\hline & Invloed & \\
\hline $\begin{array}{l}\text { Relatie met politiek en } \\
\text { beleid }\end{array}$ & Invloed groot & Invloed beperkt \\
\hline Initiatief burgers & & $\begin{array}{l}\text { Amersfoort; Groningen } \\
\text { Kruiskamp; Amsterdam }\end{array}$ \\
\hline \multirow[t]{2}{*}{ Initiatief gemeenteraad } & & Uden \\
\hline & Deliberatie & \\
\hline Communicatie & Waardering dialoog groot & $\begin{array}{l}\text { Waardering dialoog } \\
\text { beperkt }\end{array}$ \\
\hline Gesprek één dag & $\begin{array}{l}\text { Amersfoort; Amsterdam; Gro- } \\
\text { ningen }\end{array}$ & \\
\hline Gesprek meerdere dagen & & Kruiskamp \\
\hline Brainstorm en stemmen één dag & Uden & \\
\hline
\end{tabular}

overal. De onderwerpen die uit de burgertoppen naar voren komen, worden nergens direct vertaald in lokaal beleid. Wel stonden enkele thema's al op de agenda van de gemeente en is het betrekken van inwoners meer tussen de oren van de raadsleden gekomen. In het ontwerp wijkt Uden af van de andere burgertoppen, omdat hier de gemeenteraad het initiatief tot een G1000 heeft genomen. In vergelijking met de andere burgertoppen zijn de gekozen thema's concreter geformuleerd en meer gericht op beïnvloeding van het beleid. Desondanks is ook hier geen nieuw onderwerp vanuit de G1000 op de raadsagenda gekomen.

Ten derde blijkt de vorm van communicatie in beperkte mate invloed te hebben op de waardering van de gesprekken. In Groningen, Amersfoort en Amsterdam was de vorm sterk gericht op het gesprek tussen deelnemers en het uitwisselen van ideeën, in Uden lag de nadruk meer op brainstormen en stemmen. De waardering van de gesprekken in Uden is iets lager, maar verschilt niet significant van de overige burgertoppen. In vergelijking met de andere burgertoppen is de waardering van de gesprekken in Kruiskamp wel duidelijk lager. In Kruiskamp waren de gesprekken gespreid over vijf bijeenkomsten. De gedachte hierachter was dat deelnemers zich daardoor meer eigenaar zouden voelen van de thema's in de wijk. Veel mensen vielen echter in de loop van het proces af en de overgeblevenen oordeelden in meerderheid negatief over het proces en de gesprekken. 


\section{Conclusie en discussie}

De vraag die in dit artikel centraal stond, was wat de bijdrage is van burgertoppen aan de verwezenlijking van de democratische waarden insluiting, invloed en deliberatie, en of het ontwerp hierbij een verschil maakt. De eerste waarde, insluiting, wordt maar in beperkte mate gerealiseerd. De diversiteit van de groep deelnemers is beperkt, ongeacht of er is geloot of niet. Hét voorbeeld voor de G1000 is de G1000 in België. Maar ook daar leidde loting, ondanks veel media-aandacht, tot 500 bevestigde deelnemers die overwegend tot de blanke middenklasse behoren en tussen de 45 en 50 jaar oud zijn (Caluwaerts \& Reuchamps, 2014a). De organisatie van de G1000 België heeft uiteindelijk voor een noodoplossing gekozen door via netwerken en organisaties gericht groepen te benaderen, waaronder jongeren en migranten. Amsterdam heeft dit ingebouwd in de voorfase door met ambassadeurs te werken. Eerder onderzoek van Leyenaar (2009) naar burgerfora, onder andere naar het burgerforum Luchtkwaliteit Amsterdam en het burgerforum Omgevingsplan Flevoland, laat eveneens zien dat het moeilijk is om jongeren en laagopgeleiden te betrekken.

Ook de tweede waarde, invloed, is maar in beperkte mate gerealiseerd. De resultaten van de burgertoppen zijn niet op de agenda van de raad gekomen of rechtstreeks vertaald in lokaal beleid. Hierbij passen wel enkele kanttekeningen. Ten eerste zijn de toppen in Amsterdam en Groningen recent gehouden, waardoor het nog te vroeg is hier uitspraken over te doen. Meer in het algemeen kan het zo zijn dat sommige onderwerpen nu misschien niet op de politieke agenda staan, maar in een later stadium wel deel gaan uitmaken van het beleid. Ten tweede is de lokale politiek wel enthousiast geraakt over het betrekken van burgers op een G1000-achtige manier en zal zo'n vorm van participatie mogelijk vaker ingezet gaan worden. Tot slot kunnen burgers met veel van de gekozen thema's prima zelf aan de slag en is er geen rol voor de gemeente(raad). Voor zover dit leidt tot concrete activiteiten en initiatieven van burgers en nieuwe netwerken is er weliswaar geen sprake van politieke doorwerking, maar wel van sociale doorwerking.

Dit roept ook de vraag op of het de bedoeling van de G1000 is om invloed op beleid uit te oefenen. Hier wordt zowel door de initiatiefnemers als door de vertegenwoordigers van politiek en ambtenarij verschillend over gedacht. Wanneer het doel vooral is aan de hand van de gekozen thema's bewoners zelf aan de slag te laten gaan - wat bij alle burgertoppen is benadrukt - dan is het niet zo'n groot probleem dat er geen directe invloed op de (beleids)agenda van college en gemeenteraad is te zien. Onder meer in Uden en Amersfoort zien we inderdaad initiatieven van burgers ontstaan. Sommige daarvan lijken nieuwe initiatieven, andere sluiten aan of maken onderdeel uit van al bestaande praktijken. Als een G1000 daarentegen mede als middel wordt gezien om de koers van de politiek bij te sturen, dan wel (nieuwe) thema's te agenderen die door college- en raadsleden over het hoofd worden gezien, dan kan de conclusie niet anders zijn dan dat dit in geen van de onderzochte gemeenten is gelukt. De gekozen thema's blijken bovendien regelmatig al in bestaand beleid te zijn ondervangen. 
De derde democratische waarde, deliberatie, is tot op zekere hoogte gerealiseerd tijdens de burgertoppen. Zelfs als de gesprekken eerder de vorm aannemen van een brainstorm dan van een gesprek, zijn de deelnemers in meerderheid positief over de kwaliteit van het gesprek. Wel zien we dat het uitmaakt of de bijeenkomst op één dag wordt georganiseerd of verspreid over een aantal dagen. Sommige deelnemers klagen weliswaar dat de tijd soms te beperkt is om ideeën uit te wisselen en vorm te geven, maar tegelijkertijd laat Kruiskamp zien dat als de bijeenkomsten gespreid worden over meerdere dagen, mensen negatiever oordelen over de gesprekken en de neiging hebben om af te haken.

Wat betekenen deze bevindingen voor de toekomst van het instrument burgertop? Ten eerste, dat de burgertoppen er onvoldoende in slagen om de diversiteit van de deelnemersgroep te realiseren, roept vragen op over de legitimiteit van deze vorm van participatie. Het gaat vaak over dezelfde thema's, die een logisch gevolg zijn van de geringe diversiteit van de deelnemers: sociale cohesie, duurzaamheid en culturele voorzieningen. Loting blijkt geen wondermiddel om de diversiteit te garanderen. Alleen veel energie en tijd om specifieke groepen te benaderen en eventueel een beloning, zoals bij de stadsgesprekken over duurzaamheid in Utrecht, kunnen helpen om meer 'verschillende' mensen over de streep te trekken om mee te doen (Binnema \& Michels, 2015: 22).

Ten tweede, de onduidelijkheid over de relatie met de gemeenteraad en het bestuur en de invloed die men beoogt te hebben op het beleid kan op termijn leiden tot teleurstelling, omdat veel deelnemers de verwachting hebben dat de gemeente wel naar hen moet luisteren als zoveel mensen zich uitspreken. Als een burgertop ook beoogt invloed uit te oefenen op de politiek en het beleid, dan zal er bij de verdere ontwikkeling van het instrument meer aandacht moeten zijn voor de relatie met de gemeenteraad. Dit kan bijvoorbeeld doordat de gemeenteraad zich vooraf committeert aan de uitkomsten van de burgertop of door de verhouding met de gemeenteraad vooraf te formaliseren door de burgertop onderdeel te maken van de lokale besluitvormingscyclus.

\section{Literatuur}

Barber, B.R., Strong democracy. Participatory politics for a new age, Berkeley: 1984.

Binnema, H. \& A. Michels, 'Loting is geen wondermiddel', Democratic Challenge. 99 experimenten in de lokale democratie, Ministerie van Binnenlandse Zaken en Koninkrijksrelaties, Den Haag: 2015, p. 22.

Caluwaerts, D. \& M. Reuchamps, 'The G1000. Facts, figures and some lessons from an experience of deliberative democracy in Belgium', P. van Parijs (ed.), The malaise of electoral democracy and what to do about it, Brussel: 2014a, p. 10-33.

Caluwaerts, D. \& M. Reuchamps, 'Strengthening democracy through bottom-up deliberation. An assessment of the internal legitimacy of the G1000 project', Acta Politica, 2014b/2, p. 151-170.

Dahl, R.A., A preface to democratic theory, Chicago: 1956.

Dryzek, J.S. \& C. List, 'Social choice theory and deliberative democracy. A reconciliation', British Journal of Political Science, 2003/1, p. 1-28. 
Dryzek, J.S., 'The Australian citizens' parliament. A world first', Journal of Public Deliberation, 2009/1, Article 9, gevonden op: www.publicdeliberation.net/jpd/vol5/iss1/art9.

Elster, J., Deliberative democracy, Cambridge: 1998.

Ercan, S.A. \& C.M. Hendriks, 'The democratic challenges and potential of localism. Insights from deliberative democracy', Policy Studies, 2013/4, p. 422-440.

Fishkin, J., 'The Center for Deliberative Democracy', retrieved from: http://cdd.stanford. $\mathrm{edu} /$.

Fishkin, J.S. \& P. Laslett (eds.), 'Philosophy, politics \& society', Political Philosophy, 2002/2, special issue.

Fung, A., 'Varieties of participation in complex governance', Public Administration Review, December 2006, special issue with articles on collaborative public management, p. 66-75.

Fung, A., 'Putting the public back into governance. The challenges of citizen participation and its future', Public Administration Review, 2015/4, p. 513-522.

Gastil, J. \& P. Levine (eds.), The deliberative democracy handbook, San Francisco: 2005.

Geissel, B., 'How to improve the quality of democracy? Experiences with participatory innovations at the local level in Germany', German Politics and Society, 2009/27, p. 51-71.

Gutmann, A. \& D. Thompson, Why deliberative democracy?, Princeton: 2004.

Hendriks, C.M., J.S. Dryzek \& C. Hunold, 'Turning up the heat. Partisanship in deliberative innovation', Political Studies, 2007/2, p. 362-383.

Landemore, H., 'Inclusive constitution-making. The Iceland experiment', Journal of Political Philosophy, 2015/2, p. 166-191.

Leyenaar, M., De burger aan zet. Burgerforum: theorie en praktijk, Ministerie van Binnenlandse Zaken en Koninkrijksrelaties, Den Haag: 2009.

Michels, A., 'Innovations in democratic governance. How does citizen participation contribute to a better democracy?', International Review of Administrative Sciences, 2011a/2, p. 275-293.

Michels, A., 'De democratische waarde van burgerparticipatie', Bestuurskunde, 2011b/2, p. $75-84$.

Michels, A., 'Citizen participation in local policy making. Design and democracy', International Journal of Public Administration, 2012/4, p. 285-292.

Michels, A. \& H. Binnema, G1000 in Amersfoort, Uden en Kruiskamp. De realisatie van democratische waarden, working paper Ministerie van Binnenlandse Zaken en Koninkrijksrelaties, Den Haag: 2015.

Michels, A. \& L. de Graaf, 'Examining citizen participation. Local participatory policy making and democracy', Local Government Studies, 2010/4, p. 477-491.

Mutz, D., Hearing the other side. Deliberative versus participatory democracy, New York: 2006.

Pateman, C., Participation and democratic theory, Cambridge: 1970.

Sartori, G., The theory of democracy revisited, Chatham: 1987.

Smith, G., Democratic innovations. Designing institutions for citizen participation, Cambridge: 2009.

Van Reybrouck, D., Tegen verkiezingen, Amsterdam: 2013. 